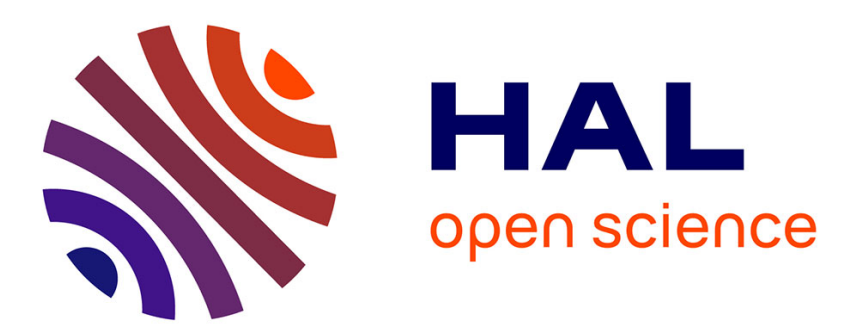

\title{
PLM Framework for the Development and Management Smart Energy Products
}

Julius Golovatchev, Oliver Budde

\section{To cite this version:}

Julius Golovatchev, Oliver Budde. PLM Framework for the Development and Management Smart Energy Products. 12th IFIP International Conference on Product Lifecycle Management (PLM), Oct 2015, Doha, Qatar. pp.698-707, 10.1007/978-3-319-33111-9_63 . hal-01377497

\section{HAL Id: hal-01377497 \\ https://hal.inria.fr/hal-01377497}

Submitted on 7 Oct 2016

HAL is a multi-disciplinary open access archive for the deposit and dissemination of scientific research documents, whether they are published or not. The documents may come from teaching and research institutions in France or abroad, or from public or private research centers.
L'archive ouverte pluridisciplinaire HAL, est destinée au dépôt et à la diffusion de documents scientifiques de niveau recherche, publiés ou non, émanant des établissements d'enseignement et de recherche français ou étrangers, des laboratoires publics ou privés.

\section{(c)(1)}

Distributed under a Creative Commons Attribution| 4.0 International License 


\title{
PLM Framework for the Development and Management Smart Energy Products
}

\author{
Julius Golovatchev ${ }^{1}$, Oliver Budde ${ }^{2}$, \\ ${ }^{1}$ Julius Golovatchev, Detecon International GmbH. \\ Deutsche Telekom Group, Cologne, Germany \\ julius.golovatchev@detecon.com \\ ${ }^{2}$ Oliver Budde, Platinion GmbH, \\ A Company of the Boston Consulting Group, Cologne, Germany \\ budde.oliver@platinion.com
}

\begin{abstract}
Utility industry has been faced with disruptive changes in their value creation process over the last decade. New technologies and regulatory pressure change the business models in the utility sector on a broad scale from power generation to utilities retail business on international markets. As a consequence utility companies need to provide complex product-service systems (PSS) to their customers in order to cope with growing customer needs on service as well as on product level. Successful player are currently introducing new product development techniques being capable to orchestrate innovation processes in complex business networks with multiples partners. As a result those companies can meet the growing need for product individualization. The foundation for implementing such a product development concepts is a comprehensive description of such Smart Energy Products, which enables different suppliers to collaborate effectively and efficiently. In this paper a conceptual product model for Smart Energy Products will be proposed as a foundation for a holistic PLM for the utility industry.
\end{abstract}

Keywords: Smart Energy Product, PLM, product complexity, utility -industry, Product-Service-Systems

\section{Motivation}

Established utility companies face a tougher business environment, in which the capability to introduce innovative products faster to the market becomes the key. Renewable energy, national and cross-border regulation, and the integration of completely new fields of application, such as electric cars, are the drivers in this development. Centralized power generation and strictly hierarchical power distribution networks will be superseded by intelligent, decentralized power generation and smart power grids. Once this transformation, a topic much discussed under the name of "smart energy", has been completed the utility sector will be characterized by a large number of smaller new providers and a start-up culture replacing the existing exclusive group of heavyweight market players (cf. Budde, O., Golovatchev, J., 2014). This change is not limited to the core area of the industry, the power generation, but will have a particularly strong impact on the interface with the customer. Clients will demand more transparency, control and freedom of choice in an increasingly competitive market. Value added services based on the information from smart power grids will be a key factor enabling electricity providers to maintain and develop their customer bases (cf. Seltitz, A., Kalkum, F. and Rieger, V.,2011). 
In the near future, customers will be demanding customized services from the utility industry going far beyond the simple provision of electric power. For instance, electromobility will give rise to the need for charging stations which can be operated by municipal utilities. Moreover, the power provider's customers will develop from being merely consumers to becoming business partners who produce electric power themselves (e.g., in their own photovoltaics installations) and may even want to sell their surplus power. (cf. Golovatchev, J., Budde O. and Felsmann, M. 2013). As a consequence of the growing demand for tailored products and the dynamics of technological developments, the range of added value services offered by power provider companies will grow and become more complex.

Currently utility companies face the following issues

- Increasing churn rates in the B2B market segment compared with the B2C business

- Although price sensitivity is a major driver for customers to switch, the individuality of the service offering as well as the customer service quality play an increasing role

- The end-to-end processes starting with the offer and ending with payment is highly dependent on efficient and flexible IT-Systems

Due to that, growth-oriented companies need to take control over:

- $\quad$ Reducing Time-to-Market

- A typical utility company has 500 products and a T2M of 2-3 months

○ Timing strategy is crucial in this market due to network effects

- $\quad$ Effective coping with increasing product variety

$\circ$ Big utility companies have to manage more than 2.500 prices in two years

- Product understanding from a pure commodity good is changing to a complex Product-Service System

In the following figure the conflict of objectives between time-to-market and a high level of product variety is shown:
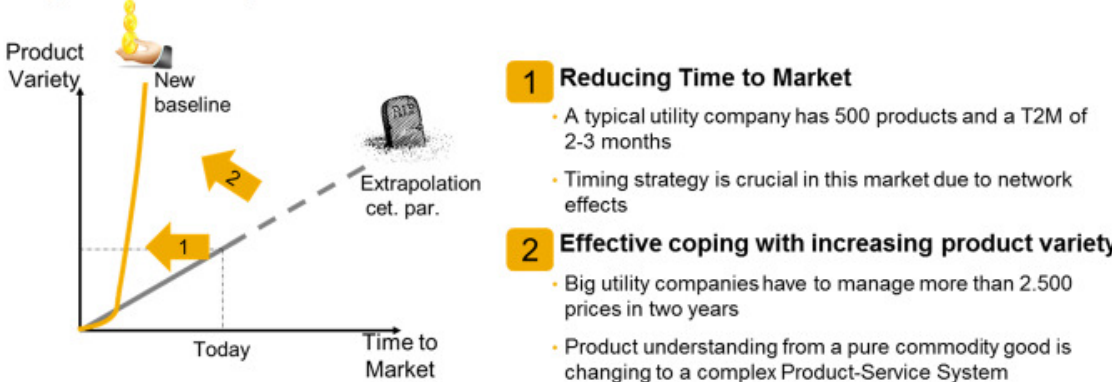

Figure 1 Balancing the goals of a high product variety and reduced time-to-market

In order to solve the conflict a holistic approach is needed, that enables the organization to develop and manage more complex products in shorter time frames compared with the situation today. As a prerequisite a sound understanding of the product 
itself needs to be established first, apparently, if otherwise the object of a corresponding management approach remains fuzzy, the whole approach cannot be efficient and effective. Therefore the next chapter will define the constitutive dimensions of the electricity-based products first.

\section{Constitutive dimensions for products in the utility industry}

Before getting to the details of a product model for the utility industry, the main characteristics that determine the product model have to be set. For our purpose we suggest the following four characteristics that apply in general for network-based Product-Service systems which can not only be found in the utility sector but also in the telecommunication or shipping logistics.

\section{Network effect}

Like in many other infrastructure based industries network effects can be identified. These effects lead to specific requirements concerning the adoption and diffusion of innovations in the market. Besides the original product benefit, utility companies have to consider the derivative product benefit, which can be controlled by them only to a limited extent

\section{Value Net}

Network industries are based on a special value configuration: the value net (Stabell, Fjeldstad 1998). Typical for this value configuration is a reciprocal production technology and a system technology (the physical net), which imposes special requirements on the coordination of value adding partners involved in the product lifecycle.

\section{Service characteristics}

The simultaneity of production and consumption as well as the integration of the external factor are characteristics of network based products. This involves the need to describe such products in 3 dimensions: potential, process and resource (Corsten, Gössinger 2007)

\section{Immateriality}

A further characteristic of the utility sector is the immateriality of the product. In contrast to physical goods and services, high fixed and low variable costs of production and sales are combined. New business models with zero marginal costs are possible only with digital goods.

Based on these considerations an existing scheme for classifying products in the telecommunication sector has been adapted to shed more light on the characteristics of products in the utility industry (ref Paper product service architecture). In order to differentiate the main network based product service systems from each other, we highlighted the characteristics for telco and energy products (figure 2). 


\begin{tabular}{|c|c|c|c|c|c|c|c|}
\hline \multirow{4}{*}{ 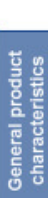 } & Attribute & \multicolumn{6}{|c|}{ Specificiation } \\
\hline & Typology of goods & Physical gooc & Servic & prot & Ily good & ormation & Energy \\
\hline & Scope of the product & \multicolumn{3}{|c|}{ Single component } & \multicolumn{3}{|c|}{ Range of components } \\
\hline & Focus of the product & \multicolumn{3}{|c|}{ Consumer focused (B2C) } & \multicolumn{3}{|c|}{ Business focused (B2B) } \\
\hline \multirow{4}{*}{ 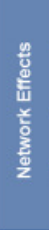 } & Network effects & \multicolumn{2}{|c|}{ direct } & \multicolumn{2}{|c|}{ indirect } & \multicolumn{2}{|c|}{ none } \\
\hline & Benefit of the product & \multicolumn{2}{|c|}{ derivative } & \multicolumn{2}{|c|}{ derivative and original } & \multicolumn{2}{|c|}{ original } \\
\hline & $\begin{array}{l}\text { Network effect } \\
\text { multiplier }\end{array}$ & \multicolumn{2}{|c|}{ Intensity of Usage } & \multicolumn{2}{|c|}{ Number of sold Items } & \multicolumn{2}{|c|}{ none } \\
\hline & $\begin{array}{l}\text { Importance of } \\
\text { Installed Base }\end{array}$ & \multicolumn{2}{|c|}{ very high } & \multicolumn{2}{|c|}{ high } & \multicolumn{2}{|c|}{ low } \\
\hline \multirow{3}{*}{ 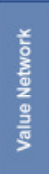 } & $\begin{array}{l}\text { Value Configuration } \\
\text { Model }\end{array}$ & \multicolumn{2}{|c|}{ Value Chain } & \multicolumn{2}{|c|}{ Value Shop } & \multicolumn{2}{|c|}{ Value Network } \\
\hline & Type of Network & \multicolumn{2}{|c|}{$\begin{array}{l}\text { Virtual Network } \\
\text { (Supply Chain) }\end{array}$} & network & $\begin{array}{l}\text { Communication } \\
\text { network }\end{array}$ & \multicolumn{2}{|c|}{ Energy network } \\
\hline & $\begin{array}{l}\text { Heterogeneity of } \\
\text { components }\end{array}$ & \multicolumn{2}{|c|}{ low } & \multicolumn{2}{|c|}{ average } & \multicolumn{2}{|c|}{ high } \\
\hline \multirow{3}{*}{ 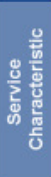 } & $\begin{array}{l}\text { Degree of technical } \\
\text { integration }\end{array}$ & \multicolumn{2}{|c|}{ low } & \multicolumn{2}{|c|}{ average } & \multicolumn{2}{|c|}{ high } \\
\hline & $\begin{array}{l}\text { Customer lasting } \\
\text { relationship }\end{array}$ & \multicolumn{2}{|c|}{ spontaneous } & \multicolumn{2}{|c|}{ average (< 1 Month) } & $\begin{array}{r}\text { contract } \\
(>1\end{array}$ & $\begin{array}{l}\text { bscription) } \\
\text { nth) }\end{array}$ \\
\hline & $\begin{array}{c}\text { Degree of } \\
\text { individualisation }\end{array}$ & $\begin{array}{r}\text { Individua } \\
\text { (craft }\end{array}$ & $\begin{array}{l}\text { product } \\
\text { ork) }\end{array}$ & Buildin & ck based & Standa & product \\
\hline & Kind of immateriality & Information & Electricity & Heat & $\begin{array}{c}\text { Radiation } \\
\text { energy }\end{array}$ & $\begin{array}{l}\text { Chemical } \\
\text { Energy }\end{array}$ & $\begin{array}{l}\text { Mechanical } \\
\text { Energy }\end{array}$ \\
\hline 言 & Storability & pos: & & & & & \\
\hline & Benefit provisioning & & direct & & & indirect & \\
\hline & Identity & & yes & & & no & \\
\hline
\end{tabular}

Figure 2 Classification scheme for network based product service systems

As it can be concluded from figure 2 the main differences between the utility and the telco product can be identified in the dimension of immateriality. For a better understanding about the nature of the energy products the differences in this dimension will be further explained:

1. Kind of immateriality

There are various types of intangible real goods. With the aim to distinguish in particular between the utility and the telecommunication industry, this feature should be differentiated at first between the generally intangible good classification of "information" and "energy" in general. Due to the fact that energy can be further concretised we suggest to differentiate between the various energy forms as well. For the purpose of the paper electricity is in the focus.

\section{Storability}

Electrical energy can be stored mostly only for a very limited time and only by expensive conversion cost into other forms of energy and is therefore viewed as not economically storable. This explains the classification as partial. In contrast to the information, that can be easily stored and copied at zero cost. This non-storability entails that there is no 
possibility of decoupling of production and consumption on the formation of storage and thus production and consumption of electricity hast take place at the same time. The problem of keeping a high availability level of power generation capacity in order to secure the energy supply at peak demand describes the structural problem of the utilities industry, which will get more intensive due to the competition as the investments could not more be covered by the revenues.

\section{Benefit provisioning}

The supply of energy generates its value solely in connection with the use of (end-) customer equipment, such as manufacturing equipment like a refrigerator or an oven. Thus, the consumer is not interested in the energy as such, but to the benefit, e.g. light or heat. This value is created by the use of electricity.

\section{Non-Identification}

It is not possible to assign the power actively fed-in by the contractor to the power extracted by the other contractor party, because the power automatically responds to changes in voltage and then flows where it current was taken. This shows that the marking of the power is nearly impossible and eventuate in Non-Identification of the key performance of electrical power.

\section{Product types in the utility sector}

A prerequisite for a systematic product management in the utility industry is the product systematization. Similar to the telecommunications industry, the product concept is difficult to grasp in network industries. Generally the product is perceived as a service, since electricity is intangible and therefore fulfills this important service characteristic.

But in difference to the general service understanding, the product in utility industry is centered on the intangible component electricity, but in addition to this several other components are essential e.g. processes like metering, as well as informational goods such as pricing information or control information for a demand -side management.

According to this understanding the product in the utility industry can be defined as a product-service system, which requires a physical energy network to provide services and consist of the variety of other material (e.g. smart meters) and intangible components (price information, installations etc).

The fundamental classification scheme, proposed in the last section, helps to understand the unique characteristics of energy products as a whole compared with Telco products or physical goods in general. In this section we will go one step further and define the solution space of product components for energy products ranging from the provisioning of electricity to Smart Energy Products.

\section{Network Feature}

This dimension characterizes the network-related performance of the product. Energy service provider can offer in addition to the power supply also gas, water and telecommunications services. This component includes services which use is made possible by the direct access to a physical network infrastructure like the power grid or telecommunications network. Typical services include the supply of electricity, the provision of network infrastructure for the conveyance or the realization of market 
communication. In the context of electric mobility the infrastructure-related performance consist of the infrastructure construction, operation and maintenance of charging stations for the the energy supply of electric vehicles.

\section{Service Feature}

This dimension describes the range of possible services which could be offered by energy service provider as the product components. Today these services include meter operation and measurement services. As has been noted already, in general a service character can be recognized for energy products. Services are an integral part of the product offering of utility companies, especially in the context of electric mobility. Typical characteristics can be maintenance services of smart meters, or energy consulting services.

\section{Information (Services)}

This dimension describes the range of information goods, which can be offered by a utility company as part of its product-service system. Especially for new business models such as smart homes or demand-side management, the availability and quality of information goods is critical to success. Information services are characterized by utilizing directly IT-systems. Therefore, it is necessary to specify the IT services exactly by service-level agreements, so that the IT value chain can be efficiently and effectively controlled.

\section{Physical goods}

As material goods may be described the tangible, man-made objects with a recordable technical function can be called (see Weber 2005, p 103). Material goods are carriers of technology and the material realization of the utilization of services. In the present context of e-mobility various material goods are necessary to provide an appropriate power system to the customers. Firstly under this category fall the electric cars itself and the other all other tangible goods that are either existentially necessary for use (e.g. the charging cable) or a product-differentiating effect (e.g. navigation equipment with vehicle-specific properties).

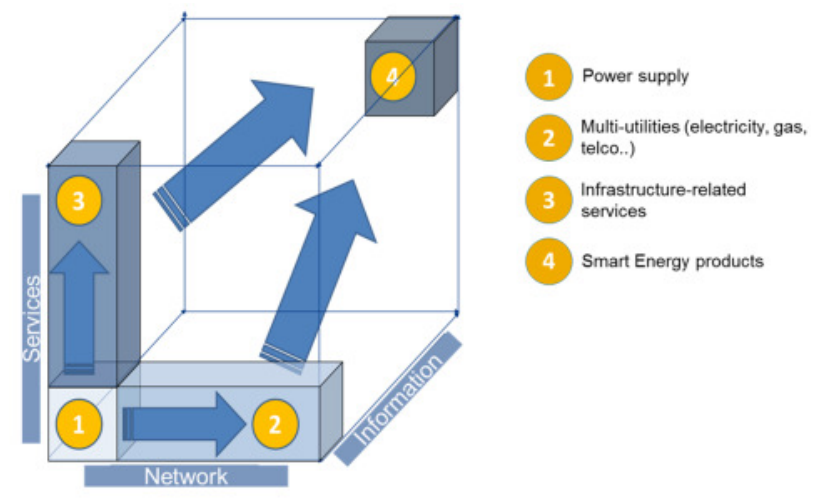

Figure 3: Feature room for energy products 
This systematization allows the modeling and design of the product in utility industry in more efficient way. In the following figure for each product category further details are provided.

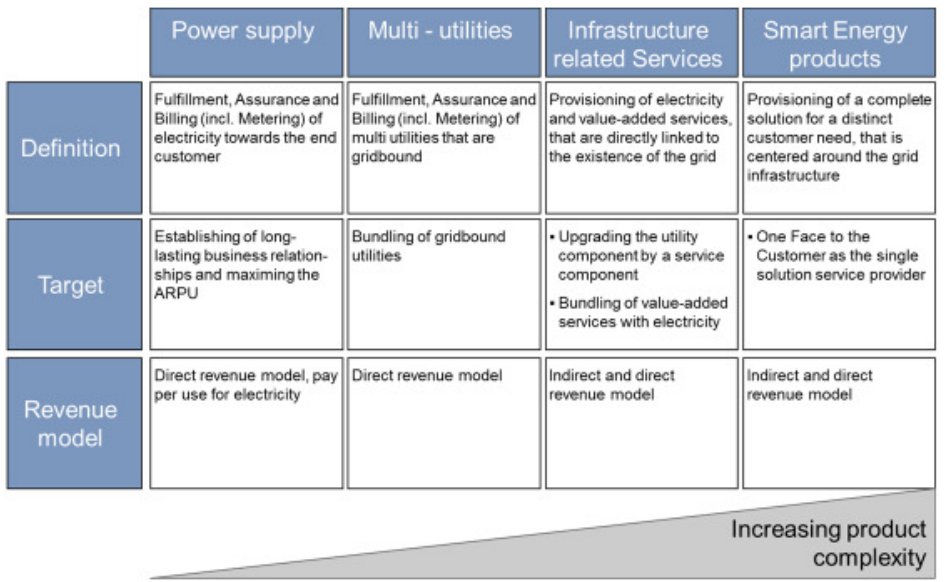

Figure 4: Details on the product categories in the utility context

This high product diversity described above requires well defined development processes as well as product structures enabling mass customization. Furthermore, the high market dynamic involves regular adjustments of the product strategies and a retirement management of old products in a systematic way.

Product lifecycle management (PLM) has the potential to cope with this complexity trap and to speed up innovations while reducing costs. In the power industry, PLM currently gains importance through the risen product complexity.

\section{PLM Approach for Smart Energy Products}

As a consequence of the growing demand for tailored products and the dynamics of technological developments, the range of added value services offered by power provider companies will grow and become more complex.

Having brought some light into the Smart Energy Product definition, the question arises why complexity is an important issue for utility industry that needs to be managed adequately. Providers must be prepared to handle the ever-increasing complexity. If they are to master the related organizational and technical IT challenges, they will have to develop a holistic product lifecycle management approach which will enable them to adapt their product portfolios quickly.

Based on the authors' experiences from several PLM implementation projects in this area, the authors have finally proposed the integrated product development and implementation framework - PLM framework for the service providers. It is based on a modified model which has been implemented successfully in the telecommunications industry, a field which is structurally related to power. The framework encompasses the four dimensions of PLM strategy, PLM process, product architecture, and PLM IT architecture and should be used from energy providers as an orientation for their processes and products in the future (cf. Budde, O., 2012) 


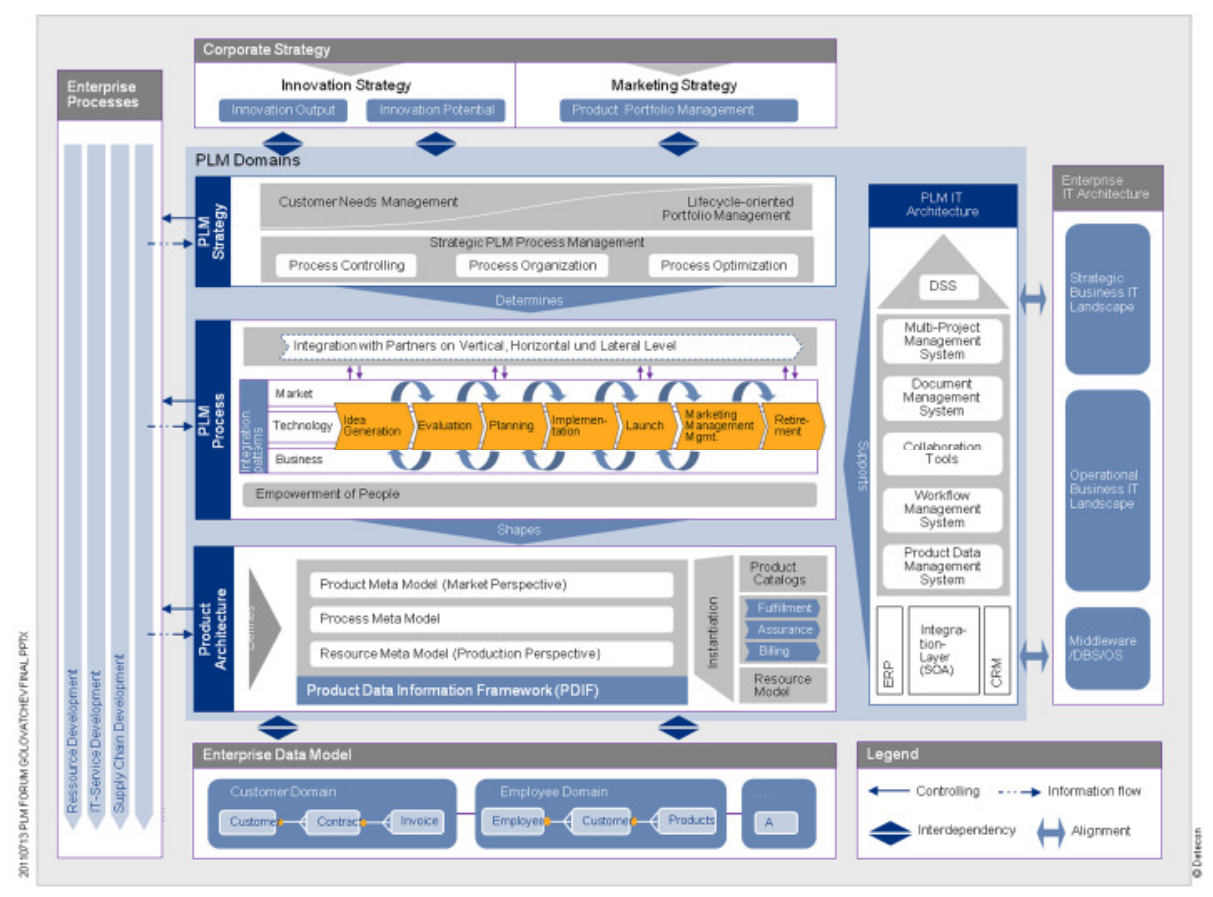

Figure 5: PLM approach for the energy sector (cf. Golovatchev, J. et al, 2010b)

\section{PLM-Strategy}

The purpose of the domain 'PLM strategy' is the alignment of the innovation and marketing strategy with the overall PLM strategy to allow for a synchronization of the product development, market management and retirement processes. In order to do so, a strong link to customer needs management has to be ensured, as well as the safeguarding of lifecycle-oriented product and project portfolio management - controlling and monitoring the innovation and product pipelines. A strategic PLM process management defines the cornerstones of the PLM process by introducing PLM process variants according to innovation level and by implementing consistence PLM process reporting.

In particular, for the utiltiy companies the design of PLM process variants and agile process play very important role by the development of various innovations. For example the development of an energy tariff, as incremental innovation, requires completely another product development process design as the introduction of new innovation complex products and services in the context of e-mobility (cf. Golovatchev, J.; Budde, O. et al, 2010b)

\section{PLM-Process}

Since PLM plays a crucial role for organizational success in such highly complex and competitive markets as the utility industry, the relevance of an adequate PLM-process is self-evident. As indicated in the earlier section, the requirements on such a PLM-process have changed. Long-living products with a limited variance in their product structure along their lifecycle are becoming less and less relevant. Those products have been replaced by a new type of product-service-system that is characterized by the fact that it 
consists of a bundle of components/modules, each with a different lifecycle and a high variance and functionality. As the product concept has changed, the PLM-process has to be adapted accordingly regarding sustainability and environmental issues.

As part of the definition of the functional integration, the organizational interfaces between the different departments and with the external value chain partners involved should be clearly defined. For electric mobility products of the utility companies it is essential to synergistically integrate these interfaces in the PLM process model.

\section{Product Architecture}

Many present quality deficiencies in the product development in the power industry originate from a diffuse definition o products as well as from the inconsistent view on the object "product". The right product architecture leads to simplification, cost optimization and sustainability of "product and service engineering" through the re-use of the production and service modules, shorten "time-to-market", avoiding overlaps in development and reduce technical variance, availability of the product modules range of all service lines (factories) for all division of the utility companies

The problem of building a modular product structure can be also solved with the appropriate product architecture. For the utiltiy industry a product modelling on the performance level (market perspective), process level (service view) as well as the physical product level (material goods and network) is required. In addition, for the modelling in these dimensions is production view (data model) for product on the appropriate level of information technology should be assured. For example, for emobility, the properties of the available plugs in the charging stations should be taken in the consideration (cf. Budde, Golovatchev 2011).

\section{PLM IT-Architecture}

Finally appropriate IT support architecture is necessary for the efficient PLM process implementation. For the companies in utility industry such a PLM ITArchitecture must support the PLM process in the dimensions: (1) Decision support, (2) Operational support and (3) integration of supplemental business applications. We suggest to rely on a PLM IT- Architecture that re-uses, respectively customizes existing IT- components as far as possible. For the product-service-systems (PSS) in the utility industry mainly the systems for the project and workflow management are essential.

In combination these four factors provide a framework for development and management of Smart Energy Products to ensure the growth for the utilities companies.

\section{Conclusion and Outlook}

The development and implementation of new business models in field of emobility will lead to entirely new product concepts which need to be developed, managed, controlled and ultimately replaced on the end of their lifecycle.

Considering the fact that these concepts are currently still emerging, this paper contributes to structure and alignment of the multitude of possible design levels or elements which are relevant for a holistic PLM.

Based on these general characteristics we have derived a detailed scheme for a further concretization of the Smart Energy Products. This definition and systematization of the 
product provides essential perspectives on the product that lead to consequences in the defining a corresponding product model for the energy service providers. Having brought some light into the Smart Energy Product definition, the question arises why complexity is an important issue for utility industry that needs to be managed adequately. Based on the authors' experiences from several PLM implementation projects in this area, the authors have finally proposed the integrated product development and implementation framework for the energy service providers.

The results of the paper will help energy service providers to develop and implement new innovative Smart Energy Products faster and with higher quality. The presented approach for the management of Smart Energy Products (PLM Framework) contributes to the appropriate configuration of innovation and product management for energy service providers.

\section{References}

Budde, Oliver (2012): Produktlebenszyklusmodell für die Telekommunikationswirtschaft. Apprimus. Aachen. Apprimus Wissenschaftsverlag.

Corsten, H.; Gössinger, R. (2003): Gestaltungsdimensionen von Dienstleistungen: Lehrstuhl für Produktionswirtschaft, Univ.

Budde, O.; Golovatchev, J. (2011): Descriptive Service Product Architecture for Communication Service Provider. In: Functional Thinking for Value Creation, p. 213-218, Springer,

Budde, O.; Golovatchev, J. (2014): Produkte des intelligenten Markts In: C. Aichele, O. D. Doleski (Hrsg.), Smart Market, p. 593-620, Springer Fachmedien, Wiesbaden,

Golovatchev, J. and Budde, O. (2013) 'Complexity measurement metric for innovation implementation and product management', Int. J. Technology Marketing, Vol. 8, No. 1, pp.82-98.

Golovatchev, J., Budde O. and Felsmann, M. (2013) 'Im Strom der Zeit: Product Lifecycle Management (PLM) als Instrument zur Beherrschung der steigenden Marktdynamik und Produktvielfalt in der Energiewirtschaft' [online] http://www.detecon.com/plm_energie (accessed 02/05/2013)

Golovatchev, J. .; Budde, O.; Hong, C. G. (2010a): Integrated PLM-process-approach for the development and management of telecommunications products in a multi-lifecycle environment. In: International Journal of Manufacturing Technology and Management, Jg. 19, H. 3, p. 224-237.

Golovatchev J., Budde O, Hong CG, Holmeckis S, Brinkmann F.(2010b): Next Generation Telco Product Lifecycle Management. How to Overcome Complexity in Product Management by Implementing Best-Practice PLM. [online] www.detecon.com/PLM (accessed 02/05/2013)

Seltitz, A., Kalkum, F. and Rieger, V. (2011): 'Smart Energy: New Values from the Energy Networks of the Future: Success Factors for New and Established Providers' [online] http://www.detecon.com/en/studies/smart-energy-new-values-from-the-energynetworks-of-the-future_2011_03_01_343 (accessed 02/05/2013)

Stabell, C. B.; Fjeldstad, O. D. (1998): Configuring value for competitive advantage: on chains, shops, and networks. In: Strategic Management Journal, Jg. 19, H. 5, p. 413-437. 